\title{
Impact of Climate Change on Wind Potential in Lithuania Territory
}

\author{
Justė JANKEVIČIENE ${ }^{1 *}$, Arvydas KANAPICKAS ${ }^{2}$ \\ ${ }^{1}$ Lithuanian Energy Institute, Breslaujos str. 3, Kaunas, Lithuania \\ ${ }^{2}$ Vytautas Magnus University, K. Donelaičio str. 58, Kaunas, Lithuania
}

\begin{abstract}
Wind energy is one of the most important ways to implement green energy in Lithuania. The development of wind energy infrastructure by state funding is directly related to wind energy resources. Changes in wind energy resources induced by ongoing climate change have not been well analyzed either in Lithuania or in Europe or worldwide. This article analyses data taken from long-term wind observations and IPCC projections. It was found that during the last decades (1980-2019), the wind speed in Lithuania decreased up to $0.69 \mathrm{~m} / \mathrm{s}$ in the coastal region and up to $0.24 \mathrm{~m} / \mathrm{s}$ in the central part of Lithuania. The decrease in wind speed caused a decrease in generated energy by $15.6 \%$ and $17.8 \%$ in the coastal and the central parts of Lithuania. Analysis of wind speed projections for the period 2010-2100, according to the $\mathrm{RCP} 4.5$ scenario, has shown that the average annual wind speed would decrease by $7.3 \%$ in Lithuanian's coastal region and $8.8 \%$ the central region by the end of the century. The change in wind speed will cause up to a $25 \%$ reduction in wind potential. As the average lifetime of wind turbines is about 25 years, the amount of electricity generated during this period will be up to $20 \%$ lower than planned at the design stage.
\end{abstract}

Keywords - Climate change; projections; wind energy potential; wind speed

\section{INTRODUCTION}

The European Union (EU) has renewable energy goals described in the directive 2018/2001 that promote the use of energy from renewable sources. The directive states that emissions should be cut by at least $40 \%$ below 1990 levels by 2030, and the share of renewable energy consumed in the EU should be at least $27 \%$ [1]. The share of renewable energy in energy consumption increased from $8.5 \%$ (2004) up to $17.5 \%$ (2017) and is expected to reach $20 \%$ by 2020 [2]. Also, the directive states that each country of the EU should reach national targets of renewable energy. For Lithuania, the target is to increase the share of renewable energy sources to at least $23 \%$ of the country's final gross energy consumption by 2020 . The share of electricity produced from renewable energy sources (RES) from $4.9 \%$ in the country's total electricity consumption in 2008 to $21 \%$ in 2020 [3], [4]. The official Statistics portal of Lithuania provides information on energy consumption in 2018. The largest energy consumption has crude oil and petroleum products $(39.6 \%)$ and natural gas $(23.1 \%)$. Renewable energy resources make $19.8 \%$, out of which $-0.5 \%$ solar energy, $2.4 \%$ hydropower, and $6.5 \%$ wind energy [5]. Lithuanian Wind Power Association (LWAP) states that $1.1 \mathrm{TWh}$ of electricity was produced, over $10 \%$ of Lithuanian's overall electricity demand. This amount of electricity was generated by 23 onshore wind parks of $539 \mathrm{MW}$ capacity (including smaller wind power plants) [6].

\footnotetext{
* Corresponding author.

E-mail address: juste.jankeviciene@1ei.lt 
Wind electricity production depends mainly on wind speed in the region of interest. Because of climate change, the amount of wind power is also changing. However, there is no clear trend identified. The summary of the latest research on the impact of climate change on renewable energy can be found here [7]. Some investigations have found out that wind speeds in the northern and central Europe have slightly increased over the past decades [8], [9]. Other studies revealed some decrease in winds [10], [11]. Lithuanian hydrometeorological service introduced new climate averages [12] over the period 1980-2010, which shows some decrease in mean speeds between two periods 1960-1990 and 1980-2010.

Wind farm developers and investors' concern about wind trends in the future because of climate change is increasing, and therefore information about wind energy potential is required.

There are many investigations worldwide and Lithuania that pay attention mostly to increase the production of energy out of renewable energy sources (RES), including wind energy. However, continually increasing production out of RES means installations of new wind farms usually, which does not describe any changes in wind potential [4], [8], [10], [11]. Because of the EU goals towards renewable energy, countries are focusing more on increasing RES share than actual wind potential. No exact data exist towards wind speed changes in Lithuania or any other EU country, especially in projected wind speed. Moreover, there is not enough information about changes in wind speed for the present in Lithuania, except for data, which is provided by the Lithuanian Hydrometeorological Service [12]. Finally - there is a lack of accurate projected wind data related to Lithuania. This paper aims to analyse projected wind potential in the country and create the wind atlas for this century.

\section{Methodology}

Observed wind speed data is taken from the Lithuanian Hydrometeorological Service (LHMS). Hourly data covers the period from 2015.01.01 until 2018.12.31 for 23 different country locations, which names correspond to the closest city. The main drawbacks of such observed data are missing measurements and limited choice of locations. For example, there is no data for the Baltic Sea seashore. Therefore, mostly hourly MERRA-2 (Modern-Era Retrospective analysis for Research and Applications, Version-2) meteorological data was used for historical data.

MERRA-2 provides climate data since 1980, such as wind speed, direction, irradiation duration, precipitation, and other parameters. MERRA data are provided for every location worldwide at the height of $2 \mathrm{~m}$ above ground level (AGL), except for wind speed and direction, provided at $10 \mathrm{~m}$ AGL [13]. Data has a spatial resolution of $0.5^{\circ} \times 0.625^{\circ}$ and the time step of $10 \mathrm{~min}, 15 \mathrm{~min}, 30 \mathrm{~min}$, day, month, or an hour. In this article, the authors chose to use hourly data as the most widely used time step. The data's reliability was checked by running quality control tests of $M E R R A$ data, which includes data validation and verification. Quality control was done by comparing LHMS and MERRA data using correlation coefficient, standard deviation, variance, monthly means, and medians. In some cases, LHMS and MERRA data have different measured and simulated values. In these cases, the bias adjustment was performed for $M E R R A$ data.

The projection of climate change induced weather parameters such as temperature, precipitation, wind speed, is being investigated by the Intergovernmental Panel on Climate Change (IPCC) - the organization which coordinates the efforts of climate scientists all over the world. The latest projections are based on the RCP - Representative Concentration Pathways, representing greenhouse gas concentration pathways adopted by the IPCC for the fifth Assessment Report in 2013-2014 [14]. Wind data was taken from three global 
circulation models: the model of the Max Planck Institute for Meteorology Earth System (MPI-ESM-LR), Institute Pierre Simon Laplace, Earth System (IPSL-CM5A-MR), and the Hadley Centre Global Environmental Model-Earth System (HadGEM2-ES).

The projection of meteorological data is based on emission scenarios RCP, which can be distinguished by the total radiative forcing in $2100: 2.6,4.5,6.0,8.5 \mathrm{~W} / \mathrm{m}^{2}$, or RCP2.6, $\mathrm{RCP} 4.5$, RCP6.0, RCP8.5, respectively. The RCP2.6 and RCP8.5 are the most contrasting scenarios: the RCP2.6 is the mildest one with approximately $490 \mathrm{ppm}$ in $\mathrm{CO}_{2}$ equivalents by 2100, while the RCP8.5 scenario is the most severe one with greenhouse concentrations reaching $1370 \mathrm{ppm}$ in $\mathrm{CO}_{2}$ equivalents by 2100 .

For future wind projections analysis, the most realistic scenario RCP4.5 was chosen in this study [14], [15]. According to this scenario, climate change in high latitude is expected to be more severe than in low latitudes, suggesting that the RCP2.6 scenario could be too mild to expect [14], [15]. Weather conditions for this scenario are determined by the increase of mean temperature by $1.4{ }^{\circ} \mathrm{C}$ (the likely range $0.9-2.0^{\circ} \mathrm{C}$ ) in the middle of the $21^{\text {st }}$ century with the following slight rise up to $1.8^{\circ} \mathrm{C}\left(1.1-2.6^{\circ} \mathrm{C}\right)$ by the end of this century. Greenhouse gas concentration for this scenario increases up to $560 \mathrm{ppm}$ in $\mathrm{CO}_{2}$ equivalent in the middle of the century, and then it is stabilized at this level [14], [15].

Daily wind data for the period 2006-2100 were obtained from the Earth System Grid Federation (ESGF) System. Wind data were then extracted from the data files, taking the wind values for the grid points covering all the Lithuania and adjacent territory. After all wind data were bias-corrected for the analysis of wind changes, the mean yearly wind speed was calculated according to all three GCMs for the RCP4.5 scenario for the middle (2041-2050) and far (2091-2100) future. Finally, the wind speed of all three GSMs was averaged and compared with the reference period of 1981-2010.

Bias correction is necessary in most cases, especially for projected data, because these data do not correspond to the observed or simulated data, as shown in Fig. 1. Many authors agree [16]-[20] that there are numerous ways to perform bias correction. Some of the methods are suitable for variables that can have negative values (e.g., temperature). In contrast, others are suitable for analyzing climatic occurrences with only positive values, such as wind speed, precipitation [17]-[19]. The most widely used methods are linear scaling, variance scaling, quantile mapping, empirical quantile mapping [16]-[20]. In this paper, for bias correction, the linear scaling method has been chosen. Corrected values for wind speed were calculated using the following equation [20]:

$$
W^{*}=a W
$$

where

$W^{*} \quad$ Corrected wind speed, $\mathrm{m} / \mathrm{s}$;

$W \quad$ Uncorrected wind speed, $\mathrm{m} / \mathrm{s}$;

a Scaling factor, which can be determined as follows:

$$
a=\frac{\bar{O}}{\bar{W}}
$$

where $\bar{O}$ is monthly mean observed wind, $\mathrm{m} / \mathrm{s}$, and $\bar{W}$ is monthly mean simulated wind speed, $\mathrm{m} / \mathrm{s}$.

Wind potential is a parameter that shows how much power can specific wind turbine produce, i.e., power available in the wind: 


$$
P=\frac{1}{2} \rho A v^{3},
$$

and wind power per unit area:

$$
P=\frac{1}{2} \rho v^{3}=\frac{p v^{3}}{2 R_{\text {specific }} \cdot T}
$$

where

$P \quad$ Power, W;

$\rho \quad$ Density of air, $\mathrm{kg} / \mathrm{m}^{3}$;

$A \quad$ Intercepted area normal to wind flow, $\mathrm{m}^{2}$;

$v \quad$ Wind speed, $\mathrm{m} / \mathrm{s}$;

$p \quad$ Absolute pressure, $\mathrm{Pa}$;

$T \quad$ Absolute temperature, $\mathrm{K}$;

$R_{\text {specific }}$ Specific gas constant for dry air, which is equal to $287.058 \mathrm{~J} /(\mathrm{kg} \cdot \mathrm{K})$ [10], [21].

For wind power calculations in this paper, Eq. (4) was used because wind power per unit area is more comfortable to compare and does not limit to a specific wind turbine type.

Some sources provide wind data at $2 \mathrm{~m}$ AGL. When necessary wind speeds were recalculated to the same height $-10 \mathrm{~m} \mathrm{AGL}$, using the following equation [8]:

$$
v_{2}=v_{1}\left(\frac{z_{2}}{z_{1}}\right)^{\alpha},
$$

where

$v_{1} \quad$ Velocity at height $z_{1}, \mathrm{~m} / \mathrm{s}$;

$v_{2} \quad$ Velocity at height $z_{2}, \mathrm{~m} / \mathrm{s}$;

$z_{1} \quad$ Lower height, m;

$z_{2} \quad$ Upper height, $\mathrm{m}$;

$\alpha \quad$ Wind shear exponent.

Usually, it is chosen to keep $z_{2}=100 \mathrm{~m}$, and $\alpha=1 / 7$. These values correspond to the average height of wind turbines and average wind shear [8], [22]-[24].

For the calculations and plot drawing, $R$ software was used [25]. It is free and can be an alternative for using many different software or tools. $R$ is widely used for statistical analysis, plotting graph, as NetCDF format reader, making maps. Even though it is possible to use $R$ for composing maps, $Q G I S$ was chosen. $Q G I S$ is an open source geographic information system (GIS) software that allows to compose maps [26]. Even though there are many replacements of $Q G I S$, this software is user-friendly, free, enhances replicability, and takes less time to produce the weather map comparing to $R$.

\section{Results}

Three different datasets were used and analyzed in this study: observed wind data, simulated (MERRA-2), and projected. A comparison of observed, simulated satellite and projected mean wind speeds is shown in Fig. 1. For 23 different hydrometeorological stations (HMS), correlation coefficient, mean, median, variance and standard deviation were calculated for all sets of daily data. These parameters revealed that MERRA weather data and 
projected data are reliable enough for further evaluations, but bias corrections are necessary for both MERRA and projected data.

It is seen in Fig. 1(a) that simulated and projected data do not match observed data. That usually happens because of the coarse resolution of global climate models [18]. Bias correction of wind speeds has been done using Eq. (1). After wind speed correction (Fig. 1(b)), MERRA, and projected wind speed data match the observed data more accurately. Coefficients of determination for each data set are given in Table 1.

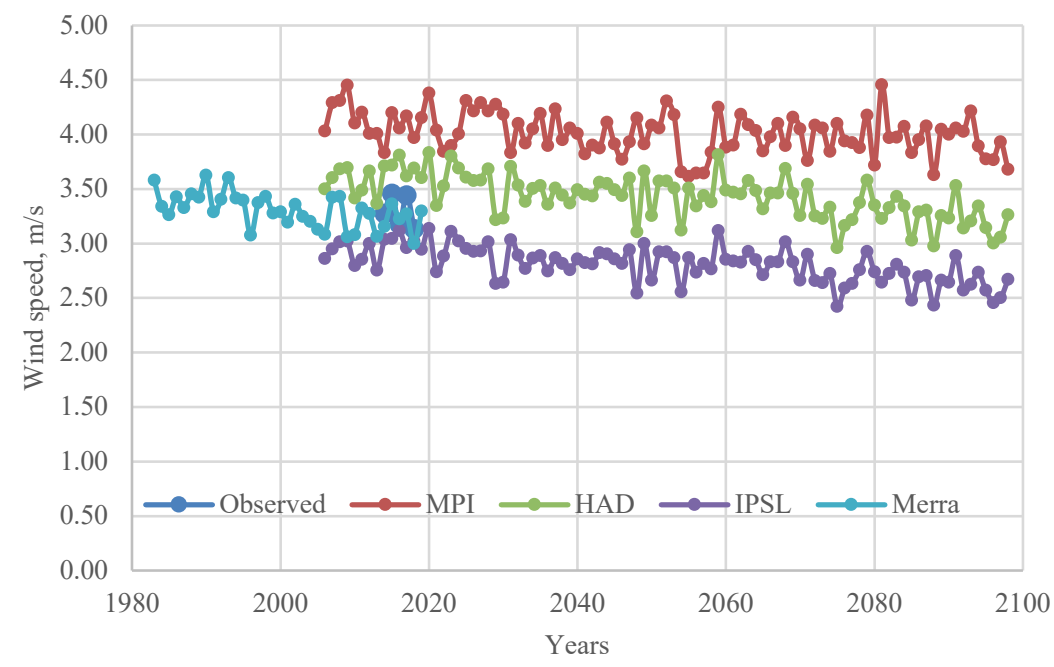

(a)

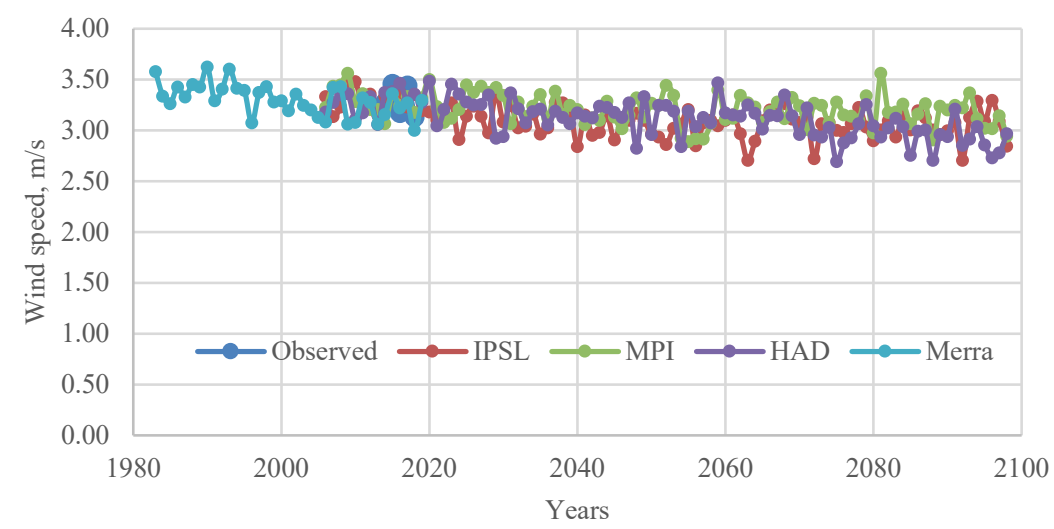

(b)

Fig. 1. Comparison of observed, MERRA-2, and projected annual mean wind speeds (a) before and (b) after bias adjustment according to observed wind speed data for Kaunas HMS.

For further analysis, the projected wind speed data for three GCM models were downscaled and then bias-corrected. A comparison of wind speeds for three different projection models and historical wind data is given in Table 1. The meaning of columns is given below the table. 
Future winds and energy potential were calculated for the middle and the far future averaging over 2040-2050 and 2090-2100 periods.

TABle 1. Wind SPEEdS AND ENERgy Potential For OBSERVEd, Simulated MERRA, AND PROJECTED WIND DATA OF 23 HMS STATIONS IN LITHUANIA

\begin{tabular}{|c|c|c|c|c|c|c|c|c|c|c|c|}
\hline City & $R^{2 \mathrm{a}}$ & $\mathrm{SD}^{\mathrm{a}}$ & $\begin{array}{l}\text { Mea } \\
\mathrm{n}^{\mathrm{a}}\end{array}$ & $\begin{array}{l}\mathrm{DC}, \\
\mathrm{m} / \mathrm{s}\end{array}$ & $\begin{array}{l}\mathrm{CN}, \\
\mathrm{m} / \mathrm{s}\end{array}$ & $\begin{array}{l}\mathrm{W} 1, \\
\mathrm{~m} / \mathrm{s}\end{array}$ & $\begin{array}{l}\mathrm{W} 2, \\
\mathrm{~m} / \mathrm{s}\end{array}$ & $\begin{array}{l}\text { W3, } \\
\mathrm{m} / \mathrm{s}\end{array}$ & $\begin{array}{l}\mathrm{E} 1, \\
\mathrm{~kW} / \mathrm{m}^{2}\end{array}$ & $\begin{array}{l}\mathrm{E} 2, \\
\mathrm{~kW} / \mathrm{m}^{2}\end{array}$ & $\begin{array}{l}\mathrm{E} 3, \\
\mathrm{~kW} / \mathrm{m}^{2}\end{array}$ \\
\hline Biržai & 0.80 & 1.25 & 2.47 & 0.14 & 2.47 & 2.44 & 2.36 & 2.29 & 49.05 & 49.57 & 45.00 \\
\hline Dotnuva & 0.62 & 1.27 & 2.67 & 0.19 & 2.69 & 2.65 & 2.51 & 2.43 & 62.84 & 58.31 & 53.84 \\
\hline Dūkštas & 0.85 & 1.22 & 2.45 & 0.18 & 2.49 & 2.44 & 2.35 & 2.28 & 50.42 & 49.80 & 45.66 \\
\hline Kaunas & 0.81 & 1.54 & 3.30 & 0.24 & 3.32 & 3.28 & 3.11 & 3.03 & 112.99 & 115.96 & 106.86 \\
\hline Kybartai & 0.86 & 1.55 & 3.22 & 0.22 & 3.26 & 3.22 & 3.06 & 2.97 & 115.87 & 109.92 & 100.21 \\
\hline Klaipèda & 0.66 & 1.42 & 3.15 & 0.69 & 3.02 & 2.98 & 2.90 & 2.82 & 90.14 & 96.23 & 85.43 \\
\hline Laukuva & 0.87 & 1.62 & 3.87 & 0.17 & 3.84 & 3.78 & 3.64 & 3.52 & 184.70 & 197.34 & 166.42 \\
\hline Lazdijai & 0.88 & 1.42 & 2.86 & 0.16 & 2.26 & 2.23 & 2.12 & 2.06 & 38.62 & 36.24 & 33.48 \\
\hline Mažeikiai & 0.86 & 1.32 & 2.74 & 0.08 & 2.48 & 2.45 & 2.41 & 2.36 & 49.45 & 56.81 & 49.25 \\
\hline Nida & 0.75 & 1.72 & 3.72 & 0.24 & 5.30 & 5.23 & 5.08 & 4.94 & 491.25 & 514.99 & 463.41 \\
\hline Panevėžys & 0.88 & 1.35 & 2.87 & 0.19 & 2.91 & 2.87 & 2.72 & 2.64 & 79.77 & 74.650 & 67.74 \\
\hline Raseiniai & 0.81 & 1.43 & 3.51 & 0.23 & 3.55 & 3.49 & 3.30 & 3.20 & 144.77 & 134.78 & 123.71 \\
\hline Rokiškis & 0.85 & 1.00 & 2.25 & 0.11 & 1.90 & 1.87 & 1.81 & 1.76 & 21.88 & 22.19 & 20.27 \\
\hline Šiauliai & 0.85 & 1.20 & 2.38 & 0.12 & 2.41 & 2.38 & 2.25 & 2.18 & 47.79 & 44.35 & 40.28 \\
\hline Šilutė & 0.87 & 1.81 & 3.59 & 0.18 & 4.18 & 4.12 & 3.97 & 3.84 & 233.75 & 248.71 & 212.26 \\
\hline Švenčionys & 0.81 & 1.04 & 1.89 & 0.13 & 1.85 & 1.82 & 1.73 & 1.68 & 20.46 & 19.97 & 18.12 \\
\hline Tauragè & 0.60 & 0.95 & 2.22 & 0.11 & 2.19 & 2.15 & 2.07 & 2.00 & 33.86 & 36.44 & 30.47 \\
\hline Telšiai & 0.91 & 1.22 & 3.12 & 0.10 & 3.16 & 3.12 & 3.03 & 2.94 & 102.82 & 112.95 & 96.06 \\
\hline Ukmergè & 0.83 & 1.39 & 2.72 & 0.20 & 2.76 & 2.72 & 2.60 & 2.52 & 68.30 & 67.00 & 60.32 \\
\hline Utena & 0.87 & 1.12 & 2.05 & 0.15 & 2.06 & 2.03 & 1.94 & 1.88 & 29.12 & 28.44 & 25.89 \\
\hline Varèna & 0.86 & 1.08 & 1.97 & 0.12 & 1.99 & 1.97 & 1.87 & 1.82 & 26.17 & 25.45 & 22.87 \\
\hline Véžaičiai & 0.51 & 1.20 & 3.47 & 0.11 & 3.34 & 3.29 & 3.18 & 3.07 & 119.69 & 128.81 & 108.74 \\
\hline Vilnius & 0.86 & 1.31 & 2.71 & 0.20 & 2.74 & 2.70 & 2.58 & 2.50 & 67.70 & 65.21 & 59.21 \\
\hline
\end{tabular}

Note: $R^{2 \mathrm{a}}$ - correlation coefficient between observed and simulated MERRA data, $\mathrm{SD}^{\mathrm{a}}$ - standard deviation of observed wind speeds, Mean ${ }^{\mathrm{a}}$ - observed mean wind speed averaged over 2014-2018; DC - wind speed decrease from 1980 to 2010, CN - climatological normal (1980-2010), W1 - mean wind speed for the period 2010-2019, m/s, W2 - mean wind speed for the middle future (2040-2050), m/s, W3 - mean wind speed for the far future (2090$2100), \mathrm{m} / \mathrm{s}, \mathrm{E} 1$ - specific wind energy power for 2010-2019, E2 - specific wind energy power for the middle future (2040-2050), E3 - specific wind energy power for far future (2090-2100).

It was found that climatological normal $(\mathrm{CN})$ is $2.87 \mathrm{~m} / \mathrm{s}$ in Lithuania's territory (19802010). This value corresponds to the specific average wind energy power density of $10.14 \mathrm{~kW} / \mathrm{m}^{2}$. Wind speed slightly decreased over the last decade (2010-2019) and now is $2.80 \mathrm{~m} / \mathrm{s}(2.44 \%)$. This change caused average specific energy power to decrease up to $9.1 \mathrm{~kW} / \mathrm{m}^{2}$ or by $10.3 \%$. The wind speed tends to decrease in the future too. Different models provided various results, showing that mean wind speed will be $2.76 \mathrm{~m} / \mathrm{s}$ (MPI-ESM-LR), $2.65 \mathrm{~m} / \mathrm{s}$ (IPSL-CM5A-MR), and $2.76 \mathrm{~m} / \mathrm{s}$ (HadGEM2-ES) by 2040-2050. For this period, the mean specific energy power will be $9.28 \mathrm{~kW} / \mathrm{m}^{2}, 8.10 \mathrm{~kW} / \mathrm{m}^{2}$, and $9.82 \mathrm{~kW} / \mathrm{m}^{2}$, respectively. For the last decade of this century (2090-2100), mean wind speed will be 2.72 
m/s (MPI-ESM-LR), $2.67 \mathrm{~m} / \mathrm{s}$ (IPSL-CM5A-MR) or $2.53 \mathrm{~m} / \mathrm{s}$ (HadGEM2-ES), while mean specific energy power would be $9.04 \mathrm{~kW} / \mathrm{m}^{2}, 8.34 \mathrm{~kW} / \mathrm{m}^{2}$ and $6.76 \mathrm{~kW} / \mathrm{m}^{2}$. For the further analysis, projected wind speed data were averaged over all three models.

All three models provide slightly different wind speed data. Therefore, it has been chosen to average the data of projections and use such values. All further calculations are based on averaged data.

The analysis of obtained data has shown that although Lithuania is a small country, the mean wind speed and specific wind energy power differ. It also follows from Table 1 that relatively small changes in wind speed can cause a significant change in wind energy power. This result can be explained by the cubic dependence of wind energy on wind speed (Eq. (3)).

The analysis of projected wind energy was carried out for four Lithuanian regions as shown in Fig. 2 and Table 2.

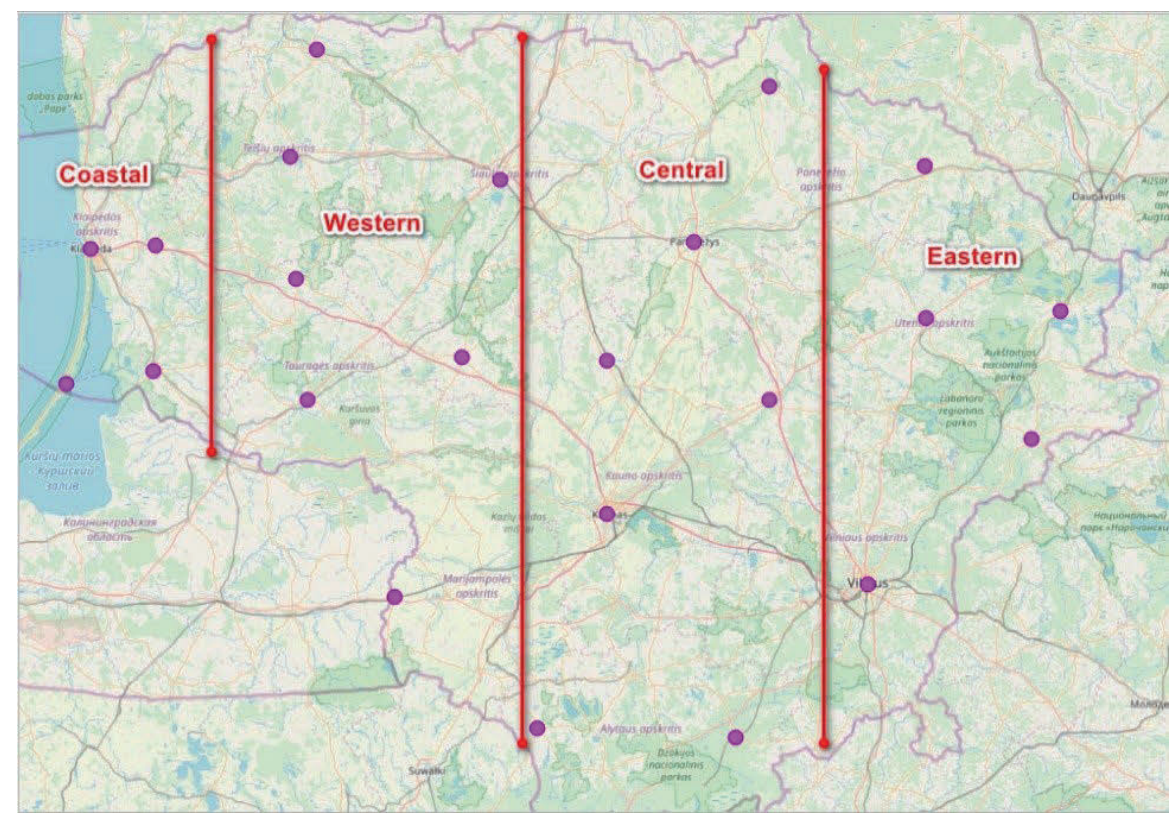

Fig. 2. Regions of hydrometeorological locations.

It was found out that climate change mostly affects the central region of Lithuania, where, by the end of the century, wind speed will decrease by $8.8 \%$ and specific energy potential by $27.3 \%$. Mild impact climate change will have on the coastal region, where wind and energy potential decrease may reach up to $7.3 \%$ and $21.6 \%$, respectively. All new wind turbine projects should be well evaluated because electricity production may be up to $21 \%$ in the central region and up to $12 \%$ in the coastal region less than at the planning stage. 
TABLE 2. Wind SPEED AND SPECIFIC ENERgy POWER In COASTAL, WeStern, CENTRAL, AND EASTERN REGIONS OF LITHUANIA.

\begin{tabular}{llllllllllllll}
\hline & Coastal region & \multicolumn{4}{c}{ Western region } & \multicolumn{3}{c}{ Central region } & \multicolumn{3}{c}{ Eastern region } \\
\hline & $\mathrm{CN}$ & $\mathrm{MF}$ & $\mathrm{FF}$ & $\mathrm{CN}$ & $\mathrm{MF}$ & $\mathrm{FF}$ & $\mathrm{CN}$ & $\mathrm{MF}$ & $\mathrm{FF}$ & $\mathrm{CN}$ & $\mathrm{MF}$ & $\mathrm{FF}$ \\
\hline $\mathrm{W}$ & 3.96 & 3.78 & 3.67 & 2.98 & 2.82 & 2.74 & 2.63 & 2.47 & 2.40 & 2.21 & 2.08 & 2.02 \\
\hline $\mathrm{E}$ & 278 & 247 & 218 & 117 & 99 & 87 & 77 & 61 & 56 & 45 & 37 & 34 \\
\hline$\Delta \mathrm{W}, \%$ & - & 4.6 & 7.3 & - & 5.4 & 8.1 & - & 6.1 & 8.8 & - & 5.9 & 8.6 \\
\hline$\Delta \mathrm{E}, \%$ & - & 11.2 & 21.6 & - & 15.4 & 25.6 & - & 20.8 & 27.3 & - & 17.8 & 24.4 \\
\hline
\end{tabular}

Note: CN - climatological normal (1980-2010), MF - middle future (2040-2050), FF - far future (2090-2100), $\mathrm{W}$ - wind speed, $\mathrm{m} / \mathrm{s}, \mathrm{E}$ - energy, $\mathrm{kW} / \mathrm{m}^{2}$.

The wind speed distribution in the territory of Lithuania was obtained over 1980-2010. Historical mean wind speed data were further used as a base value for the analysis. It should be noted that values obtained in this study correspond to the mean speeds published by the Lithuanian Hydrometeorological Service [12] but are more detailed. The distribution of wind speed means over Lithuania territory over 1980-2010 (actually, climatological normal) is shown in Fig. 3(a). The change of wind speeds over the last decade is given on the right side. As can be expected, wind speed is highest in coastal (i.e. western) Lithuania. Also, the decrease in wind speed is smaller in coastal region comparing to the central part of the country, where the reduction reaches up to $0.12 \mathrm{~m} / \mathrm{s}$ per decade. The most part of the eastern region encounter similar wind speed decrease as in coastal region.

The comparison of the mean wind speed for the RCP4.5 scenario averaged over three GCM projection data is presented in Fig. 4. The picture below shows wind speed change in the middle (a) and far (b) future. Least affected regions by climate change are the eastern and the southern part of the central region, where the decrease of projected wind speed would be the highest, reaching up to $0.20-0.24 \mathrm{~m} / \mathrm{s}$ over $2090-2100$, while the southern part of the coastal region will lose $0.32 \mathrm{~m} / \mathrm{s}$ or more.

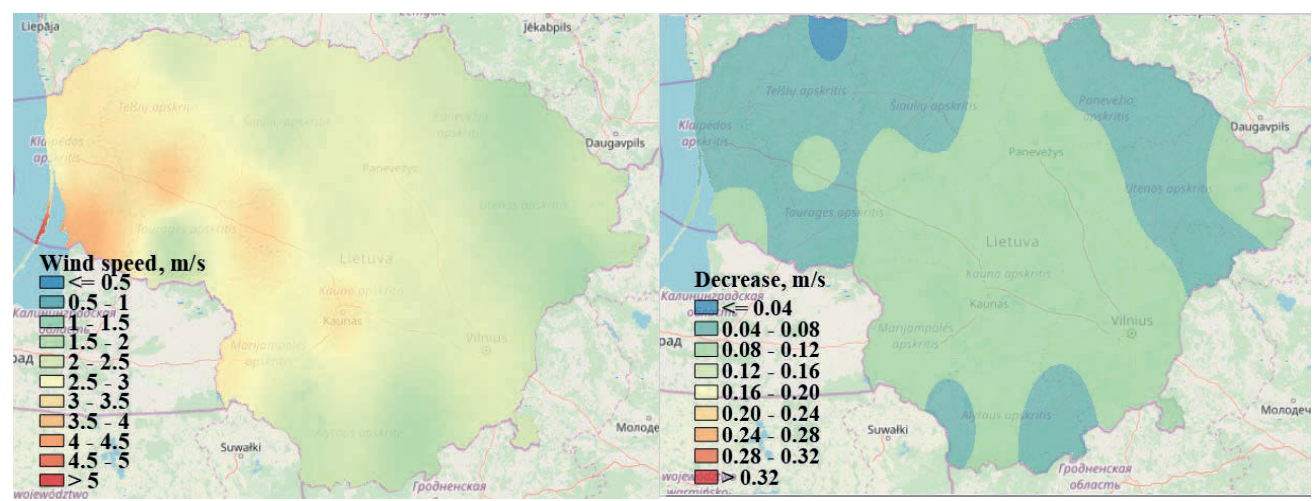

(a)

(b)

Fig. 3. (a) Climatological normal (1980-2010) of wind speed in Lithuania, and (b) the change of wind speeds over the last decade (2010-2019). 


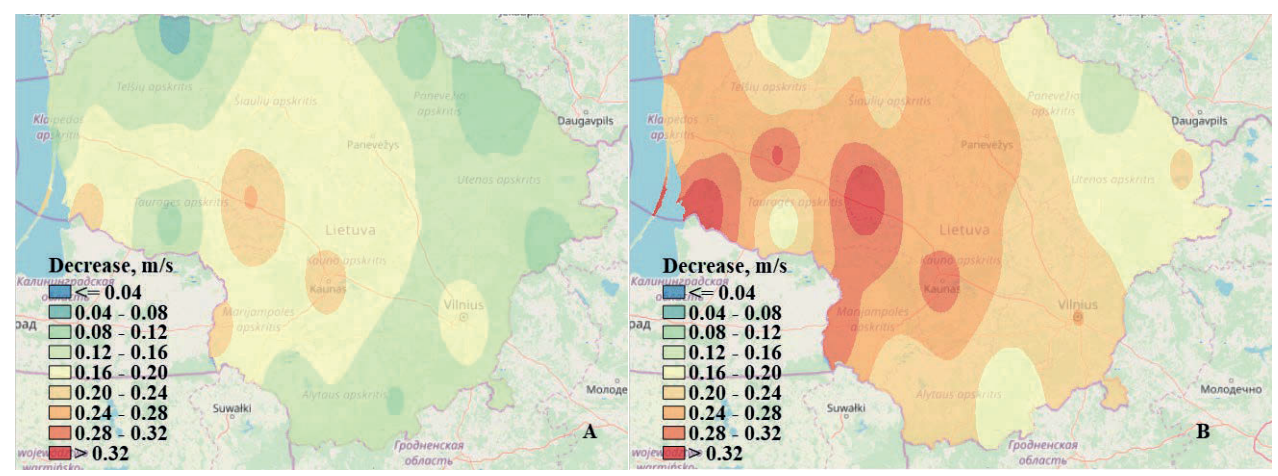

Fig. 4. Wind speed change in the future, comparing to CN: (A) 2040-2050; (B) 2090-2100.

The summary of projected wind speed until the end of the $21^{\text {st }}$ century in Lithuania is shown in Fig. 5. It is seen that the curve of historical wind speed data is steeper comparing to the projected wind speed data. Even though only 2 sites are presented in Fig. 5 (Vilnius HMS and Kaunas HMS), the same situation applies to all analyzed sites. The difference in wind speed change rates between observed and projected wind speed data suggests that the RCP4.5 scenario is not the most realistic one.

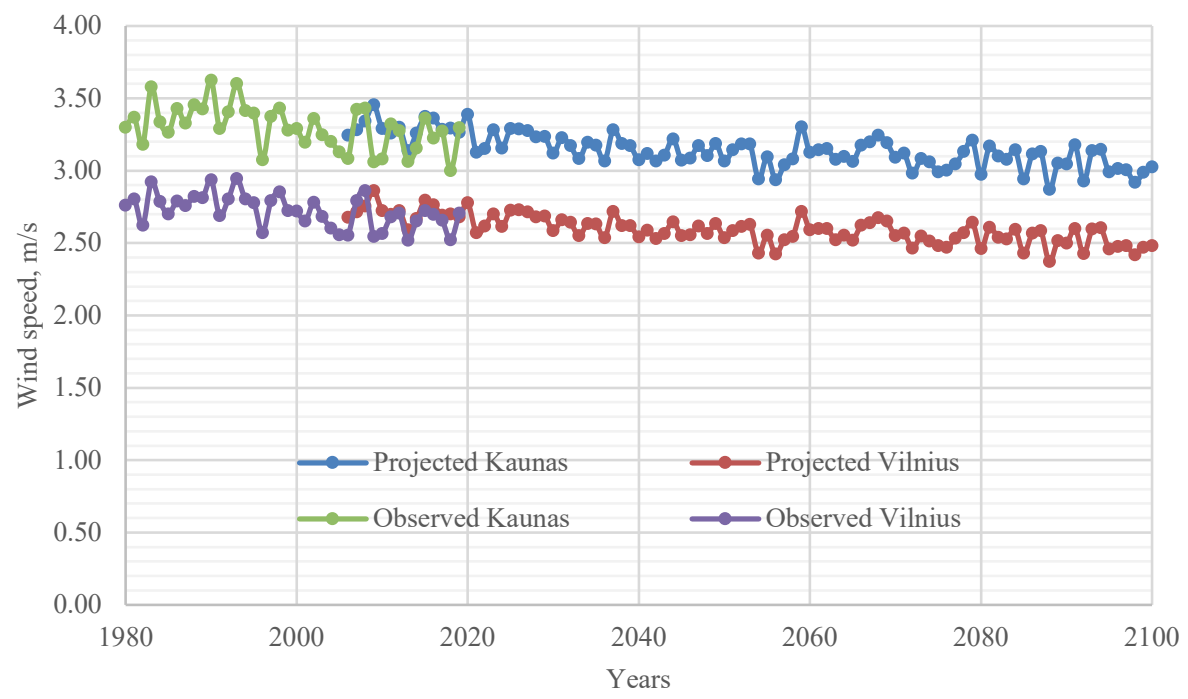

Fig. 5. Wind speed change over the century in Vilnius and Kaunas.

\section{Discussion}

The analysed wind speed decrease can be explained considering the pattern of global atmospheric circulation. Warm air masses are transferred to higher latitudes and cold air masses to the lower latitudes. The intensity of this process (or the strength of winds) is determined by the temperature difference between higher and lower latitudes. Because of ongoing climate change, the increase of temperature at lower latitudes is much smaller than 
the warming at higher latitudes [14], [27]. This difference in temperature trends leads to the decrease of temperature is driven mass transfer and, consequently, to the global decrease of wind speeds [28]-[30]. Although the results obtained in this investigation have shown a decrease in wind speed and energy, the analysis of the latest research on the impact of climate change on renewable energy revealed some disagreements. Some authors state that wind speed has slightly increased over the last decades [8], [9], while others have found some decrease [10], [11]. This research supplements the findings of the Lithuanian hydrometeorological service on decreasing wind speed. The results suggest that wind energy potential in the country should be reconsidered. It was obtained that by the end of the century, wind speed decrease will cause a huge loss in wind potential - up to $27.3 \%$. This result was based on the most realistic RCP4.5 scenario, using three different averaged climate change models. However, the analysis of the data given in Fig. 5 suggests that this scenario could be too mild. Therefore, other climate change scenarios (the mildest RCP2.6 and the most severe RCP8.5) should be included in the evaluation of wind energy potential. In addition, the IPCC [14] and some authors [27] warn that greater climate change is expected in mid-latitudes and high-latitudes. That should be taken into considerations when planning and building wind turbines or wind farms. As follows from the results presented in this study, payback period is going to elongate. Also, wind speed decrease may cause difficulties to reach sustainability's goals [31], [32].

\section{Conclusions}

In this paper, the impact of climate change on wind potential has been analyzed. Results have shown that over the last decades (1980-2019), wind speed decreased by $17 \%$ in coastal and by $9 \%$ in central regions of Lithuania. That caused wind potential reduction by up to $18 \%$. Analysis of projected wind speed data for the RCP 4.5 scenario, using three different models, has shown that in the middle future (2040-2050) wind speed decrease by $7.3-8.8 \%$ comparing to climatological normal. This result leads to the conclusion that the reduction of generated electricity may reach up to $20 \%$ in the final period of wind turbine exploitation. Further analysis has revealed that by the last decade of the century (2090-2100), wind potential will decrease by $27 \%$ in the far future (2090-2100) comparing to historical wind potential data, while wind speed decrease will be up to $9 \%$ at the same time. The most severe decrease in wind speed and wind potential is expected to be observed in the central region of Lithuania.

\section{REFERENCES}

[1] Directive (EU) 2018/2001 of the European Parliament and of the Council of 11 December 2018 on the promotion of the use of energy from renewable sources. Official Journal of European Union 2018: L 328/82.

[2] Eurostat. [Online]. [Accessed 20.02.2020]. Available: https://ec.europa.eu/eurostat/

[3] Ministry of Energy, Ministry of environment. National renewable energy action plan. Vilnius: Ministry of Energy of the Republic of Lithuania, 2010.

[4] Blumberga A., et al. Modelling the Baltic power system till 2050. Energy Conversion and Management 2016:107:6775. https://doi.org/10.1016/j.enconman.2015.09.005

[5] Official Statistics Portal [Online]. [Accessed 20.02.2020]. Available: https://osp.stat.gov.lt/informaciniaipranesimai? eventId $=200543$

[6] Lithuanian wind power association (LVEA), statistics of Lithuania. [Online]. [Accessed 20.02.2020]. Available: https://lvea.lt/en/statistics/lithuanian-statistics/

[7] Solaun K., Cerda E. Climate change impacts on renewable energy generation. A review of quantitative projections. Renewable and Sustainable Energy Reviews 2019:116:1-16. https://doi.org/10.1016/j.rser.2019.109415 
[8] Weber J., Gotzens F., Witthaut D. Impact of strong climate change on the statistics of wind power generation in Europe. Energy Procedia 2018:153:22-28. https://doi.org/10.1016/j.egypro.2018.10.004

[9] Carvalho D., et al. Potential impacts of climate change on European wind energy resources under the CMIP5 future climate projections. Renewable Energy 2017:101:29-40. https://doi.org/10.1016/j.renene.2016.08.036

[10] Cosseron A., et al. Characterization of the Wind Power Resource in Europe and its Intermittency. Energy Procedia 2013:40:58-66. https://doi.org/10.1016/j.egypro.2013.08.008

[11] Shipkovs P., et al. Research of the wind energy resource distribution in the Baltic region. Renewable Energy 2013:49:119-123. https://doi.org/10.1016/j.renene.2012.01.050

[12] Lithuanian Hydrometeorological Service (LHMS). Climate averages for Lithuania 1981 - 2010. 2013. [Online]. [Accessed 20.02.2020]. Available:

http://www.meteo.lt/documents/20181/103901/Lietuvos_klimatas_09_25.pdf/e307f875-d20b-4a4d-aa90c66a4dd57885

[13] MERRA-2 [Online]. [Accessed 20.02.2020]. Available: https://gmao.gsfc.nasa.gov/reanalysis/MERRA-2/

[14] The Intergovernmental Panel on Climate Change (IPCC). The Climate change 2014: Synthesis Report. Contribution of Working Groups I, II and III to the Fifth Assessment Report of the Intergovernmental Panel on Climate Change. Geneva: IPCC, 2014.

[15] van Vuuren D. P., et al. The representative concentration pathways: an overview. Climatic Change 2011:109:5. https://doi.org/10.1007/s10584-011-0148-Z

[16] Luo M., et al. Comparing bias correction methods used in downscaling precipitation and temperature from regional climate models: a case study from the Kaidu river basin in Western China. Water 2018:10(8):1046. https://doi.org/10.3390/w10081046

[17] Holman, B. P., Lazaris, S. T., Splitt, M. A fetch-based statistical method to bias correct and downscale wind speed over unresolved water bodies. Weather and forecasting 2017:32:1637-1657. https://doi.org/10.1175/WAF-D-17-0016.1

[18] Li D., et al. Statistical bias correction for simulated wind speeds over CORDEX-East Asia. Earth and Space Science 2019:10:200-211. https://doi.org/10.1029/2018EA000493

[19] Zhang T., et al. Bias-correction method for wind speed forecasting. Journal of Arid Meteorology 2017:28(4):10421052. https://doi.org/10.1127/metz/2019/0950

[20] Lafon T., et al. Bias correction of daily precipitation simulated by a regional climate model: a comparison of methods. International Journal of Climatology 2013:33:1367-1381. https://doi.org/10.1002/joc.3518

[21] Byrne R., et al. An assessment of the mesoscale to microscale influences on wind turbine energy performance at a periurban coastal location from the Irish wind atlas and onsite LiDAR measurements. Sustainable Energy Technologies and Assessments 2019:36:100537. https://doi.org/10.1016/j.seta.2019.100537

[22] Manwell J., F., Mcgowan J. G., Rogers A. L. Wind energy explained. Wiltshire: John Willey \& Sons. 2009.

[23] Troen I., Lundtang P. E. European wind atlas. Roskilde: Risø National Laboratory. 1989.

[24] Albani A., Ibrahim M. Z., Yong K. H. Wind shear data at two different terrain types. Data in brief 2019:25:104306. https://doi.org/10.1016/j.dib.2019.104306

[25] R software - Rstudio [Online]. [Accessed 20.02.2020]. Available: https://rstudio.com/

[26] Qgis project [Online]. [Accessed 20.02.2020]. Available: https://www.qgis.org/lt/site/

[27] Rind D. The consequences of not knowing low- and high-latitude climate sensitivity. Bulletin of the American Meteorological Society 2008:89:855-864. https://doi.org/10.1175/2007BAMS2520.1

[28] Nikulin G., et al. Evaluation and future projections of temperature, precipitation and wind extremes over Europe in an ensemble of regional climate simulations. Tellus A: Dynamic Meteorology and Oceanography 2011:63(1):41-55. https://doi.org/10.1111/j.1600-0870.2010.00466.x

[29] Lorenz D. J., DeWeaver E. T. Tropopause height and zonal wind response to global warming in the IPCC scenario integrations. Journal of Geophysical Research. Atmospheres 2007:112(D10):D10119. https://doi.org/10.1029/2006JD008087

[30] Haugen J., Iversen T. Response in extremes of daily precipitation and wind from a downscaled multi-model ensemble of anthropogenic global climate change scenarios. Tellus A: Dynamic Meteorology and Oceanography 2008:60(3):411-426. https://doi.org/10.1111/j.1600-0870.2008.00315.x

[31] Martinez C. I. P., Cotte Poveda A. The importance of science, technology and innovation in the green growth and sustainable development goals of Colombia. Environmental and Climate Technologies 2021:25:29-41. https://doi.org/10.2478/rtuect-2021-0003

[32] Blumberga D., et al. Energy, bioeconomy, climate change and environment nexus. Environmental and Climate technologies 2019:23(3):370-392. https://doi.org/10.2478/rtuect-2019-0102 